Elzbieta Tkocz

KaTOWICE

\title{
FORMACYJNY WYMIAR ŚWIATOWYCH DNI MŁODZIEŻY
}

Benedykt XVI w przemówieniu do Kurii Rzymskiej 22 grudnia 2008 roku, stwierdził, że fenomen Światowych Dni Młodzieży staje się coraz częściej przedmiotem analiz. Papież zauważył jednak, że „w popularnych obecnie analizach istnieje tendencja do uważania tych dni za pewną odmianę współczesnej kultury młodzieżowej, za coś w rodzaju festiwalu rockowego w sensie kościelnym, którego gwiazdą jest Papież”". Co więcej, „pojawiają się także głosy katolickie, wypowiadające się w tym samym duchu, według których wszystko to jest wielki spektakl, owszem piękny, ale nie mający wielkiego znaczenia dla kwestii wiary i obecności Ewangelii, w naszych czasach"2. W kontekście tych papieskich spostrzeżeń, pojawia się pytanie, które stanowi główny problem niniejszej refleksji: jaka koncepcja chrześcijańskiej formacji wyłania się z obchodów ŚDM? Poszukując odpowiedzi na tak postawione pytanie nie można pominąć prawie trzydziestoletniej już tradycji tych spotkań. W pierwszej kolejności postaram się w skrócie przedstawić rozumienie pojęcia „formacja”, następnie genezę, założenia i strukturę obchodów ŚDM, aby w związku z tym ukazać formacyjną wartość tych wydarzeń. Tematyka jest obszerna, dlatego skoncentruję się na tych elementach ŚDM, poprzez które w sposób najbardziej wyraźny zarysowuje się ich formacyjny charakter.

\section{Co rozumiemy pod pojęciem formacja?}

W Encyklopedii Katolickiej, formacja w pojęciu ogólnym określana jest jako „wywieranie trwałych wpływów przez jedną osobę, grupę, instytucję na osobowość innego człowieka w celu ukształtowania w nim (zgodnie z odpowiednim modelem) psychicznych struktur poznawczo-oceniających z internalizacją systemu przekonań i systemu wartości oraz wytworzenia wypływających z nich umiejętności działań w określonym kierunku. (...) W procesie formacji odbiorca jest podmiotem aktywnym, gdyż sam najtrafniej ocenia potrzeby własnego rozwoju i jego indywidualny

1 Benedykt XVI, Przemówienie do Kurii Rzymskiej 22 grudnia 2008r. http://www.opoka.org.pl/ biblioteka/W/WP/benedykt_xvi/przemowienia/kuria_22122008.html

2 Tamże. 
charakter. Formacja jest więc działaniem towarzyszącym i stymulującym samorozwój osoby" ". Nas jednak bardziej niż formacja w znaczeniu ogólnym, interesuje formacja chrześcijańska. O niej to mówi i ją określa Jan Paweł II w adhortacji apostolskiej o powołaniu i misji świeckich w Kościele i świecie „Christifideles Laici”. Papież wyraźnie zaznacza, że „formacja chrześcijańska” jest to „stały proces osobistego dojrzewania i upodabniania się do Chrystusa, zgodnie z wolą Ojca, pod kierunkiem Ducha Świętego" (ChL 57). W Deklaracji o wychowaniu chrześcijańskim dokonano rozdziału pomiędzy pojęciami wychowanie i formacja. Dokument ten i inne podkreślają, że wychowanie obejmuje wszystkich, natomiast o formacji jest mowa, gdy chodzi o specyficzne rodzaje powołania i zadania np. formacja zakonna, kapłańska, laikatu ${ }^{4}$.

Jak zauważa P. Tomasik, formacja chrześcijańska, której istotą jest wspomaganie rozwoju religijnego, adresowana jest do ludzi znajdujących się na różnym poziomie rozwoju wiary. Tak definiowana formacja, jest ukierunkowana na interioryzację wartości religijnych i pogłębienie świadomości sakramentalnej i eklezjalnej. $\mathrm{Z}$ natury adresowana do ochrzczonych wypełnia funkcję wychowania religijnego, czyli kształtowania postaw, nauczania (formacji intelektualnej) oraz wtajemniczenia (formacji liturgiczno-sakramentalnej, wspólnotowej) ${ }^{5}$. Natomiast A. Zellma, analizując nauczanie Kościoła na temat formacji świeckich konkluduje, że celem formacji chrześcijańskiej jest wspieranie ochrzczonych w osiąganiu dojrzałości ludzkiej i chrześcijańskiej oraz przezwyciężanie rozłamu pomiędzy wyznawaną wiarą a życiem codziennym ${ }^{6}$. W tym procesie formacji ważną rolę spełnia spotkanie z drugim, znaczącym człowiekiem i poddanie się mniej lub bardziej świadomie jego oddziaływaniom wychowawczym.

\section{Geneza i cel ŚDM}

„Nikt nie wymyślił Światowych Dni Młodzieży. Oni sami je stworzyli” (św.Jan Paweł II).

Pomysł spotkań Papieża z młodymi całego świata zrodził się w Roku Świętym, który obchodzono w całym Kościele od 25 marca 1983 roku do 22 kwietnia 1984

\footnotetext{
3 Z. Chlewiński, Formacja, w: Encyklopedia Katolicka KUL, t. 5, red. L. Bieńkowski i in., Lublin 1989, kol. 389.

4 Zob. M. Nowak, Wychowanie, w: Wokół katechezy posoborowej, red. R. Chałupniak, J. Kochel, J. Kostorz, W. Spyra, Opole 2004, s. 434.

5 Zob. P. Tomasik, Nauczanie religii w szkole jako podstawa formacji chrześcijańskiej, w: „Studia Gdańskie” XXIII (2008), s. 185.

6 Zob. A. Zellma, Katolicka Szkoła Nowej Ewangelizacji Św. Filipa jako jedna z form permanentnej formacji świeckich katolików, w: Katecheza ewangelizacyjna. Poszukiwanie koncepcji, red. P. Mąkosa, Lublin 2010, s.230.
} 
roku. W Niedzielę Palmową w 1984 roku przybyła do Rzymu liczna rzesza młodzieży z różnych krajów. Ogromna frekwencja młodych ludzi została przez Jana Pawła II odczytana jako wyraz ich głębokiej, wewnętrznej potrzeby gromadzenia się, dzielenia doświadczeniem spotkania z Bogiem, składania świadectwa wiary, a przez to wspomagania siebie nawzajem w wyznawaniu i głoszeniu swojej wiary w Chrystusa. Jan Paweł II w związku z Międzynarodowym Rokiem Młodzieży, ogłoszonym przez ONZ (1985), zaprosił młodych z całego świata do Rzymu na Niedzielę Palmową 1985. Zaproszenie przyjęło ok. 300 tysięcy pełnych entuzjazmu młodych ludzi. Od tego spotkania rozpoczęła się tradycja obchodów Światowego Dnia Młodzieży, a Niedziela Palmowa została ogłoszona Międzynarodowym Dniem Młodzieży. Począwszy od roku 1986 ŚDM obchodzone są każdego roku w diecezjach, a co dwa lub trzy lata pod przewodnictwem Ojca Świętego w wyznaczonym przez Niego miejscu na świecie. W roku 2016 w Krakowie odbędzie XXXI spotkanie o charakterze międzynarodowym.

W liście do kard. E. F. Pironio o znaczeniu Światowych Dni Młodzieży, Ojciec Święty, Jan Paweł II pisał: „zasadniczym celem Dni jest skupienie wiary i życia każdego młodego człowieka wokół osoby Jezusa tak, aby On stał się trwałym punktem odniesienia oraz prawdziwym światłem dla każdej inicjatywy i dla wszelkich działań (...) Taki jest refren każdego Światowego Dnia". W założeniu inicjatora, św. Jana Pawła II, cel ŚDM jest więc wręcz tożsamy z celem, jaki jest stawiany procesowi formacji chrześcijańskiej. W tym miejscu należy postawić pytanie, jakie elementy formacji można znaleźć w obchodach ŚDM?

\section{Troska o integralny charakter formacji}

Formacja ma ze swojej istoty charakter integralny, gdyż chodzi o pełny i wszechstronny rozwój człowieka. W przytaczanej już definicji formacji znajdujemy stwierdzenie, że jej odbiorca to aktywny, twórczy podmiot tego procesu. Sama zaś formacja, w założeniu jest ukierunkowana na stymulowanie samorozwoju osoby we wszystkich jej wymiarach, czyli intelektualnym, emocjonalnym, moralnym, społecznym, duchowym ${ }^{9}$. W tym kontekście, istotny wydaje się być następujący szczegół: otóż treści orędzi, przemówień, homilii i papieskich rozważań podczas obchodów Światowych Spotkań, są kierowane do samej młodzieży. Mają one charakter

\footnotetext{
7 Zob. Jan Paweł II, Znaczenie Światowych Dni Młodzieży, List do kard. Eduardo Pironio, L’OsRomPol 7-8(1996), s.4.

8 Tamże.

9 Zob. Z. Chlewiński, Formacja, dz. cyt.; por. P. Tomasik, Nauczanie religii w szkole jako podstawa formacji chrześcijańskiej, art. cyt., s.186.
} 
dialogu ${ }^{10}$. Właśnie ta forma pobudza młodych do samodzielnego myślenia, poszukiwania odpowiedzi, interioryzacji rozpoznanych wartości i wcielania ich w życie. Młodzież jest zapraszana do twórczego przyjmowania orędzia chrześcijańskiego. Zdaniem św. Jana Pawła II dialog to styl, dzięki któremu może być zrealizowany „rozległy program nawrócenia do Chrystusa”"11. W tym miejscu zarysowuje się papieska koncepcja formacji chrześcijańskiej. Wyraża się ona w stawianiu młodym ludziom wzajemnie uzupełniających się pytań. Pytania te można ująć w trzy grupy tematyczne: kim jest młody człowiek dla siebie, dla Boga i dla świata ${ }^{12}$. Ten dialogiczno-pytający charakter Spotkań pomaga ich uczestnikom odpowiedzieć na nurtujące pytania okresu dorastania: kim jestem i jak powinienem przeżyć swoje życie, aby go nie zmarnować? Są to podstawowe pytania egzystencjalne budzące się w okresie adolescencji. Podejmowanie ich podczas obchodów ŚDM skłania młodzież do refleksji, służąc jednocześnie formacji ludzkiej. Ta z kolei stanowi integralną część formacji chrześcijańskiej. Papieskie odpowiedzi na pytania nurtujące młodych, uczestnicy rozważają podczas charakterystycznych dla każdego spotkania międzynarodowego, wieczorno-nocnych czuwań modlitewnych. Treści te są także pogłębiane w grupach językowych podczas trzydniowych spotkań zwanych triduum katechetycznym. Wszystko to skłania młodzież do aktywnego udziału w spotkaniach, co jest istotne dla formacji chrześcijańskiej.

W wyborze i kontynuacji dialogicznej formy rozmowy z młodzieżą jest widoczna psychopedagogiczna intuicja zarówno Jana Pawła II, jak i jego następców. Teksty papieskie zawierają liczne odniesienia do prawidłowości rozwojowych okresu dorastania. Na szczególną uwagę zasługuje tu jednak List do Młodych Jana Pawła II, często nazywany „encykliką młodych”. Jego tekstem wiodącym jest ewangeliczny opis spotkania bogatego młodzieńca z Chrystusem. Opis ten bowiem, zdaniem Papieża, zawiera w sobie głęboką prawdę o człowieku, a nade wszystko prawdę o ludzkiej młodości ${ }^{13}$. Poprzez osobę ewangelicznego młodzieńca Jan Paweł II pomaga młodym zobaczyć niejako ich własne odbicie. Pytanie ewangelicznego młodzieńca przekłada na język współczesny. Papież tłumaczy młodym, że w postawie ewangelicznego młodzieńca wyraża się pragnienie odkrycia pełnej wartości życia i jego sensu. Warto jednak zaznaczyć, że papież przestrzega przed niebezpieczeństwem tłumaczenia zjawiska pytań natury egzystencjalnej jedynie

\footnotetext{
10 Zob. E.Tkocz, Inspiracje Światowych Dni Młodzieży dla młodzieżowego duszpasterstwa katechetycznego w parafii, w: Abyśmy podtrzymywali nadzieję. Ksiegga Jubileuszowa ku czci ks. prof. R. Murawskiego, red. P. Tomasik, Warszawa 2005, s.306.

11 Jan Paweł II, Znaczenie Światowych Dni Młodzieży, dz. cyt., s.4.

12 Zob. E. Tkocz, Chrześcijańska formacja młodzieży w świetle orędzi Jana Pawła II na Światowe Dni Młodzieży, Katowice 2005, s.

13 Jan Paweł II, List Apostolski „Parati Semper” z okazji Międzynarodowego Roku Młodzieży 1985, w: Jan Paweł II do młodych, Kraków 2000, s. 28-29n.
} 
na fundamencie psychologii ${ }^{14}$. Egzystencjalne spojrzenie młodego człowieka na samego siebie stanowi w papieskim dialogu z młodymi punkt wyjścia do poszukiwań Boga. Nie odrywając młodzieży od jej ludzkich przeżyć i doświadczeń kieruje ją w stronę transcendencji. Takie ukierunkowanie dialogu papieża z młodymi stanowi kolejny, ważny, element w formacji chrześcijańskiej. Uświadamia młodym, że są oni podmiotem w dialogu z Bogiem. Właśnie Bóg oczekuje od nich współdziałania w rozwoju wiary. Ważne jest tu każde pytanie wypowiedziane przez młodych przed Bogiem i poszukiwanie na nie odpowiedzi w świetle słowa Bożego.

Rolę dialogu z młodymi Jan Paweł II podkreślił przed IV ŚDM w 1990 r. mówiąc: „W moim dialogu z wami ten Dzień ma znaczenie specjalne, pozwala mi bowiem przemówić nie tylko do młodzieży jednego kraju, ale do młodzieży całego świata i powiedzieć wszystkim oraz każdemu z osobna: Papież patrzy na was $z$ wielka miłościa i $z$ wielka nadzieja, uważnie was słucha i pragnie odpowiedzieć na wasze najgłębsze oczekiwanie" ${ }^{15}$ Należy w tym miejscu zaznaczyć, że prowadząc ten dialog Jan Paweł II i kolejni papieże nie patrzą na młodzież jak na monolit. Uwzględniają uwarunkowania kulturowo-społeczne i polityczne, w których wzrasta kolejne młode pokolenie. Zwracają się do gospodarzy, wskazując na elementy ich dorobku kulturowego oraz sygnalizują charakterystyczne zagrożenia i zadania. I tak np. młodych Europejczyków przestrzegają przed odcinaniem się od kulturowego dziedzictwa, które wyrosło z chrześcijaństwa, a Amerykanom przypominają o godności człowieka i jego prawie do życia. Odniesienie do dóbr kultury, korzystanie z dziedzictwa kulturowego i pomnażanie go wpisuje się w integralną formację chrześcijańską. Stanowi bowiem ważny element, bez którego nie można mówić o autentycznej, pogłębionej formacji chrześcijańskiej, przygotowującej do składania świadectwa wiary w najbliższym środowisku.

\section{Formacja doktrynalna}

W procesie formacji chrześcijańskiej istotnym elementem jest formacja doktrynalna. Ma ona decydujące znaczenie w rozwoju intelektualnym młodzieży. Przyczynia się do poznania treści wiary, a przez to do rozumnego wyznawania wiary. W jaki sposób formacja doktrynalna jest realizowana podczas ŚDM? Otóż w licznych fragmentach papieskich tekstów dotyczących nauczania Kościoła na temat wiary i moralności, odnaleźć można odniesienia do ważnych dokumentów kościelnych oraz zachętę młodzieży do ich lektury. Wymieniane są tytuły soborowych i posoborowych dokumentów i tak np. Jan Paweł II najczęściej powoływał się na Konstytucję duszpasterską o Kościele w świecie współczesnym oraz encyklikę

\footnotetext{
14 Zob. Tenże, Głoszenie Chrystusa waszym powołaniem. Jubileusz katechetów i nauczycieli religii 10.12.2000, L'OsRomPol 2(2001), s. 45n.

15 Jan Paweł II, Orędzie na IV ŚDM 1989, L’OsRomPol 12(1998) nr 12, s.3
} 
„Redemptor hominis”, Benedykt XVI przywoływał np. encyklikę Redemptoris missio, a papież Franciszek Katechizm Kościoła Katolickiego. Zwłaszcza ten ostatni dokument zawiera systematyczną wykładnię podstawowych prawd wiary i norm życia chrześcijańskiego. Odwołują się do niego autorzy programów i podręczników katechetycznych.

Wśród metod pracy formacyjnej wyróżniona jest, zarówno podczas obchodów centralnych, jak i przygotowań do Spotkań, refleksja nad słowem Bożym. Ewangelii przypisana jest priorytetowa rola. Nie bez znaczenia jest fakt, że hasło każdego ze światowych spotkań to fragment Pisma świętego. Zawiera ono wezwanie, podejmuje problem. Każde zatem wezwanie pobudza młodych do myślenia i zajęcia określonego stanowiska. w tym też uwidacznia się rola formacyjna. Na każdym światowym spotkaniu podawane są młodym pod refleksję określone podstawowe prawdy nauczania ewangelicznego. Przed Jubileuszowym spotkaniem w 2000 roku Jan Paweł II zwraca się do młodzieży: „Niech Ewangelia stanie się dla Was najważniejszym skarbem - studiując wnikliwie Słowo Boże i wielkodusznie je przyjmując, znajdziecie w nim pokarm i siły do codziennego życia"16. Warto zauważyć, że Papież zachęcając młodych do słuchania i poznawania Słowa Bożego w swoich grupach, poleca metodę „lectio divina”. Metoda ta wymaga również aktywnego udziału młodych. Jest zatem ważna w procesie chrześcijańskiej formacji młodych.

\section{Formacja liturgiczno-sakramentalna}

Chrześcijańska formacja z natury jest ukierunkowana chrystocentrycznie. Chrystocentryczny charakter obchodów ŚDM znajduje swój punkt kulminacyjny w budzeniu świadomości sakramentalnej. ŚDM zarówno w swojej treści, jak i strukturze wyraźnie są skoncentrowane na doprowadzaniu młodych ludzi do świadomego, czynnego i pełnego uczestnictwa w sakramentach. Służą temu najpierw rozważania, jakie Papież prowadzi z młodzieżą. Rozpoczyna je od uświadomienia młodym ludziom konieczności gruntownego przemyślenia ich istoty. Papież nie narzuca młodym określonych postaw i poglądów, lecz - zgodnie z naturą formacji chrześcijańskiej - zachęca do osobistej refleksji. Tym samym po raz kolejny wskazuje na znaczenie aktywności młodzieży w poznawaniu i rozwijaniu wiary. Ojciec Święty Jan Paweł II zauważa, że istnieje duża ignorancja młodych w dziedzinie życia sakramentalnego ${ }^{17}$. Należy zaznaczyć, że konferencje połączone z celebracjami liturgicznymi nie są jedynie wykładami o sakramentach, lecz w atrakcyjny dla młodych sposób wprowadzają ich we wspólne świętowanie liturgii, szczególnie Eucharystycznej, która jest kulminacyjnym punktem każdego ze Spotkań. Stałym elementem wpisanym w tradycję obchodów ŚDM jest celebracja

16 Jan Paweł II, Orędzie na XV ŚDM 2000, L’OsRomPol 9-10(1999), s.17.

17 Zob. Tenże, Orędzie na VII ŚDM 1992,L’OsRomPol 2(1992), s.6. 
sakramentu pojednania, odbywająca się w przygotowanych wcześniej tzw. „strefach pojednania"18. Istotną rolę pełni w tych celebracjach liturgicznych, postulowane w dydaktyce katechetycznej, wyzwalanie radości spotkania z żywym Chrystusem w znakach sakramentalnych oraz budzenie potrzeby wypowiedzenia tej radości poprzez śpiew, muzykę, modlitwę ${ }^{19}$. Taki styl wspierania młodzieży w formacji postaw liturgicznych zakłada aktywność uczestników spotkań. Jest to typowe dla formacji chrześcijańskiej, w której zaangażowanie podmiotu spełnia ważną rolę.

\section{Eklezjalny i apostolski wymiar formacji}

W założeniu pomysłodawcy, św. Jana Pawła II ŚDM nie mogą mieć jednak charakteru spontanicznie improwizowanych „akcji”. Dlatego Jan Paweł II przy współpracy z Papieską Radą do spraw Świeckich wypracowywał zręby tematyczne i pastoralne dla każdego z tych spotkań. Poprzez swoje orędzia wprowadzał młodych w tę tematykę. W wyżej przywoływanym Liście Apostolskim „Parati Semper” z 1985 roku adresowanym do młodzieży z okazji proklamowanego przez ONZ Międzynarodowego Roku Młodzieży (1985), Papież wytyczył główne linie rozwojowe procesu chrześcijańskiej formacji. Natomiast treść kolejnych orędzi wprowadza młodzież w szczegółową problematykę w obrębie przewidzianego na dany rok konkretnego tematu spotkania. Nie bez znaczenia jest fakt, że główne wątki, doświadczenia i zobowiązania z Dnia Młodzieży w danym roku, są młodym przypominane podczas kolejnego spotkania. Zarysowuje się tu spójna koncepcja treści orędzi. Widać wyraźnie kontynuację, rozwijanie i pogłębianie papieskiej myśli. I tak np. w orędziu na VII ŚDM „Idźcie na cały świat i głoście Ewangelię”(Mk 16,15), Papież nawiązuje do akcentu kończącego VI ŚDM: „Taki właśnie sens miał końcowy akt częstochowskiego spotkania, gdy waszym przedstawicielom wręczyłem zapalone świece, wzywajac wszystkich młodych, by do każdego zakatka globu zanieśli światło Chrystusa. Tak, rzeczywiście na Jasnej Górze Duch Święty zapalił światło, które jest znakiem nadziei dla Kościoła i dla całej ludzkości" ${ }^{20}$.

Wypracowane zręby tematyczne i pastoralne dla każdego ze światowych spotkań. stanowią także wytyczne dla programu pastoralnego w skali Kościoła Powszechnego na czas duchowych przygotowań do centralnych obchodów ŚDM. Swoje praktyczne przełożenie znajdują w opracowywanych programach, które powinny być realizowane podczas całorocznych spotkań formacyjnych w parafiach. „Światowy Dzień jest bowiem nie tylko świętem, ale także poważnym duchowym zadaniem. Aby był on owocny, potrzebne jest przygotowanie się don pod kierunkiem

18 Zob. E.Tkocz, Inspiracje Światowych Dni Młodzieży dla młodzieżowego duszpasterstwa katechetycznego w parafii, dz. cyt. ,s. 309

19 Zob.W. Kubik, Zarys dydaktyki katechetycznej, Kraków 1990, s.132.

20 Jan Paweł II, Orędzie na VII ŚDM 1992, dz. cyt., s. 6. 
pasterzy $w$ diecezjach $i$ w parafiach, $w$ stowarzyszeniach, ruchach oraz kościelnych wspólnotach młodzieżowych"21. O tym zamyśle św. Jana Pawła II przypominał Benedykt XVI: „Przede wszystkim należy pamiętać - mówit - że Światowe Dni Młodzieży nie sa jedynie doświadczeniem tego tygodnia, w czasie którego staja sie one publicznie widoczne dla świata. Istnieje długa droga przygotowań zewnętrznych $i$ wewnętrznych, która do nich prowadzi"22. Jan Paweł II nieustannie wskazywał parafię jako na szczególne miejsce, $w$ którym z pomocą duszpasterzy dorastający ludzie mogą wzrastać oraz poznać i przeżywać misterium Kościoła. W jednym ze swoich orędzi apelował do młodych: „Musicie odkryć Kościół parafialny, jego życie (....) oraz liczne wspólnoty, które w nim istnieja i działaja" ${ }^{\prime 3}$. W gruncie rzeczy, w przywołanych słowach papieża widoczne są zalecenia dla duszpasterstwa katechetycznego w parafii, związane ze stałą i integralną formacją młodych. Ponadto po raz kolejny papieże przypominają o znaczeniu aktywnego (nie tylko zewnętrznego, ale i wewnętrznego) udziału młodych w spotkaniach formacyjnych organizowanych przez duszpasterzy. Wskazują też na znaczenie wspólnoty. Spotkania młodych w grupach pozwalają doświadczyć na czym polega bycie we wspólnocie i jakie znaczenie ma wspólnota dla rozwoju wiary. Z natury, służą też wzajemnemu oddziaływaniu młodych, co jest istotne w formacji chrześcijańskiej. Uczestnicy spotkań $\mathrm{w}$ parafiach nie tylko są aktywnym podmiotem formacji, ale również słowem i przykładem wpływają mniej lub bardziej świadomie na formację innych rówieśników. To oddziaływanie widoczne jest również podczas ŚDM. Spotkanie w jednym miejscu przedstawicieli młodych z całego świata, wspólne słuchanie słowa Bożego, udział w liturgii, wspólny śpiew i modlitwa, dialog z papieżem spełnia ważną rolę formacyjną. Wzmacnia oddziaływania formacyjne. Pozwala doświadczyć, na czym polega wspólnotowy i eklezjalny wymiar wiary. Poza tym motywuje do większego, osobistego zaangażowania.

Przygotowania do obchodów ŚDM mają jednoznacznie charakter liturgiczno-eklezjalny. Są programowane w perspektywie roku liturgicznego. Począwszy od Adwentu zaprasza się młodych do całorocznych spotkań formacyjnych we wspólnotach parafialnych. Program duchowych przygotowań osadzony jest wręcz w całokształcie duszpasterstwa parafialnego. Można odważyć się na stwierdzenie, że od poziomu duszpasterstwa parafialnego w dużym stopniu zależy owocność realizacji programu duchowych przygotowań. W teoretycznych założeniach autorów programu, czyli Krajowego Biura ŚDM, w każdej parafii powinna powstać mała grupa formacyjna, która co miesiąc będzie trwała na adoracji i wspólnotowej modlitwie $\mathrm{w}$ intencji ŚDM. Na treść proponowanych materiałów do przeprowadzenia poszczególnych spotkań składają się: konferencje tematyczne, konspekty

\footnotetext{
21 Tenże, Orędzie na V ŚDM 1990, L’OsRomPol 10-11(1989), s.32

22 Benedykt XVI, Przemówienie do Kurii Rzymskiej 22.12.2008r., http://www.opoka.org.pl/biblioteka/W/WP/benedykt_xvi/przemowienia/kuria_22122008.html

${ }^{23}$ Jan Paweł II, Orędzie na V ŚDM 1990, dz. cyt., s.32.
} 
pracy w małych grupach, medytacje biblijne do indywidualnego wykorzystania, wideo komentarze do niedzielnych Ewangelii oraz propozycję wspólnotowej celebracji i zadań apostolskich ${ }^{24}$. Cennym elementem spotkań w parafiach jest zawarta w materiałach formacyjnych propozycja zadań apostolskich. Służą one wychowywaniu młodych ludzi do odpowiedzialności misyjnej. W ramach tych spotkań zaleca się zaangażowanie młodych w konkretne sposoby pomocy materialnej wspólnotom kościelnym np. w Kazachstanie, Rosji, Białorusi i Ukrainie ${ }^{25}$. Warto zauważyć, że propozycja tego typu działalności sprzyja zaangażowaniu młodzieży „luźno” związanej z parafią. Młodość bowiem w naturalny sposób predysponuje do podejmowania inicjatyw o charakterze wolontariackim, którym przyświecają wzniosłe wartości i ideały. I tu po raz kolejny widoczne jest, typowa dla formacji chrześcijańskiej, zaangażowanie młodych. W każdym wymiarze tej formacji mają oni być aktywnym podmiotem. Co więcej, „duch” młodości i naturalna potrzeba działania sprawia, że umożliwianie młodzieży okazji do czynienia dobra, a przez to do składania świadectwa wiary, należy wykorzystać jako szansę na apostolstwo. W ten sposób formacja chrześcijańska młodzieży zostanie dopełniona o istotny element, bez którego nie można mówić o jej integralnym wymiarze.

Wyżej wymienione materiały stanowią praktyczną pomoc nie tylko dla koordynatorów diecezjalnych, lecz także dla wszystkich duszpasterzy i katechetów. Stały i integralny, a zarazem nieustannie aktualizowany (wraz z tematyką kolejnych ŚDM) charakter owej formacji chrześcijańskiej, zdaje się być warty zwrócenia szczególnej uwagi katechetów i duszpasterzy. Na podkreślenie zasługuje fakt, że owe materiały praktyczne umożliwiają realizowanie w parafiach ukierunkowanego programu formacyjnej pracy z młodzieżą i to w skali całego kraju. Wartość takiej możliwości jest wyjątkowa także dlatego, że kierunek dla tych działań duszpastersko-katechetycznych wytycza praktycznie sam papież poprzez treść kolejnych swoich orędzi do młodych.

Podsumowując niniejszą refleksję, można stwierdzić, że ŚDM zarówno co do treści, jak i struktury mieszczą się w koncepcji integralnej formacji chrześcijańskiej opisanej w dokumentach katechetycznych Kościoła (Ogólna Instrukcja Katechetyczna, adhortacja „Catechesi tradendae”, DOK). Podobnie, jak wyżej wymienione dokumenty, w założeniach ŚDM ujmuje się cel i etapy formacji, jako procesu który doprowadzić ma wierzących do pełni życia chrześcijańskiego. W elementach zarówno duchowych przygotowań, jaki i centralnych obchodów ŚDM zarysowuje się wyraźnie troska o formację ludzką, doktrynalną, liturgiczno-sakramentalną i eklezjalną. Główne linie rozwojowe formacji realizowanej poprzez ŚDM wytyczył inicjator, św. Jan Paweł II w swoim Liście Apostolskim „Parati Semper”

\footnotetext{
${ }^{24} \mathrm{http} / / / \mathrm{www} \cdot k r a k o w 2016 . c o m / \mathrm{pl} / \mathrm{swiatowe}$-dni-mlodziezy,czt-ze-slowem

25 Zob. Program duchowy „Oddać Mu pokłon. Sześć etapów w drodze do Kolonii”, Siedlce 2004, s.4; por. Polskie dary serca - przydział diecezji, http://www.sdm.org.pl ; http://www.krakow2016.com/ $\mathrm{pl} /$ swiatowe-dni-mlodziezy,czt-ze-slowem
} 
z 1985 roku. Obecne w Liście wątki tematyczne są w sposób konsekwentny i spójny realizowane i rozwijane podczas kolejnych obchodów Dni. Model, jaki się z nich wyłania to stała, a zarazem integralna formacja. Każdy uczestnik tych spotkań jest traktowany jako podmiot i zachęcany do aktywnego udziału w tej formacji.

W papieskiej wizji, proces wychowania w wierze łączony jest integralnie z prawidłowościami rozwojowymi okresu dorastania. Młody człowiek powinien najpierw zrozumieć kim jest, aby mógł zrozumieć, kim jest dla Boga i jaka powinna być jego postawa wobec świata. Te główne etapy procesu formacji rozwijane w oficjalnych orędziach poprzedzających poszczególne Światowe Dni Młodzieży. Treść każdego orędzia przypomina, kim jest młody człowiek, jaka powinna być jego relacja do Boga i do świata. Papieskie nauczanie, nie odrywając młodzieży od jej ludzkich przeżyć i doświadczeń, kieruje ją w stronę transcendencji. ŚDM ukierunkowane są chrystocentrycznie. Punktem dojścia w chrześcijańskiej formacji ma być Chrystus, który najpełniej działa w sakramentach. Stąd działania organizatorów ŚDM zarówno podczas centralnych obchodów, jak i duchowych przygotowań, są ukierunkowane na aktywny udział młodych ludzi w liturgii, aby mogli oni doświadczyć obecności Jezusa żyjącego w sakramentach. Formacji liturgicznej i kształtowaniu u młodzieży świadomości eklezjalnej służy program duchowych przygotowań do centralnych obchodów ŚDM. Uwzględnienie tego programu w całościowym planie parafialnego duszpasterstwa katechetycznego jako wyraz troski o stałość formacji, stwarza możliwość zdynamizowania istniejących form pracy we wspólnotach kościoła parafialnego, o którym często młodzi ludzie mówią, że „jest nudno i nic się nie dzieje"26. Wydaje się więc uzasadnione na stwierdzenie, że skuteczność ŚDM w ich wymiarze formacyjnym w głównej mierze zależy od poziomu duszpasterstwa parafialnego. W tym kontekście, tytułem podsumowania pozwolę sobie raz jeszcze przytoczyć słowa Benedykta XVI: „Przede wszystkim należy pamiętać - mówił że Światowe Dni Młodzieży nie sa jedynie doświadczeniem tego tygodnia, w czasie którego staja się one publicznie widoczne dla świata. Istnieje długa droga przygotowań zewnętrznych $i$ wewnętrznych, która do nich prowadzi" ${ }^{27}$. Sam Pomysłodawca ŚDM, nie tylko akcentuje konieczność przygotowań, ale także kontynuacji formacji. Podczas rozważania przed «Anioł Pański» 27 sierpnia 2000r. Jan Paweł II powiedział: „Światowy Dzień Młodzieży jest tylko etapem drogi, którą trzeba dalej iść. Po powrocie do swojego kraju każdy młody człowiek wezwany jest, by jeszcze głębiej związał się z Ewangelią i żył zgodnie z nią" ${ }^{28}$.

\footnotetext{
${ }_{26}$ Zob. M. Łaszczyk, Zagrożenia i szanse rozwoju stowarzyszeń i ruchów religijnych $w$ Kościele, RT 28-29(1991-1992) z.6.

27 Benedykt XVI, Przemówienie do Kurii Rzymskiej 22.12.2008r., http://www.opoka.org.pl/biblioteka/W/WP/benedykt_xvi/przemowienia/kuria_22122008.html

28 Jan Paweł II, Rozważanie przed Anioł Pański w Castel Gandolfo 13.08.2000, L’OsRomPol 10(2000), s.11.
} 


\section{FORMATIONAL DIMENSION OF WORLD YOUTH DAY}

\section{Summary}

The article, in great detail, describes World Youth Day and emphasizes its formational dimension. First of all, the formational dimension is analysed, then the genesis, assumptions and the structure of the WYD celebration and its purpose are discussed. In the more distant part of the article, the author indicates the formational value of these events and the concern about the integral character of the formation that takes place in WYD. The article singles out the doctrinal, liturgical-sacramental, common and apostolic formation. The source of reflection that was provoked are numerous statements of the Popes and addresses on WYD. This analysis clearly states that WYD comprises, as far as content and the structure are concerned, an integral concept of Christian formation. In conclusion, the author lists conditions of the effectiveness of formational actions that take place during WYD which are specific indicators of the chaplaincy.

Keywords: World Youth Day, Christian formation, youth catechesis 